\title{
Spatial analysis of wet spell probability over India (1971-2005) towards agricultural planning
}

\author{
Prabir Kumar DAS ${ }^{1 *}$, Dilip Kumar DAS ${ }^{2}$, Subrata Kumar MIDYA ${ }^{3}$, \\ Soumya BANDYOPADHYAY ${ }^{1}$ and Uday RAJ ${ }^{4}$ \\ ${ }^{1}$ Regional Remote Sensing Centre-East (NRSC), Newtown, Kolkata, West Bengal, India \\ ${ }^{2}$ Department of Agricultural Chemistry and Soil Science, University of Calcutta, Kolkata, West Bengal, India \\ ${ }^{3}$ Department of Atmospheric Sciences, University of Calcutta, Kolkata, West Bengal, India \\ ${ }^{4}$ National Remote Sensing Centre, Hyderabad, India \\ *Corresponding author; email: prabir111@gmail.com
}

Received: October 18, 2017; accepted: October 14, 2019

\begin{abstract}
RESUMEN
Se realizó un análisis espacial de la probabilidad de ocurrencia de periodos húmedos en la región india utilizando datos reticulares $\left(0.5^{\circ} \times 0.5^{\circ}\right)$ de precipitación de 1971 a 2005 durante el periodo del monzón de verano, i.e., junio-septiembre. Se aplicó un umbral a la precipitación semanal acumulada para convertir los datos de precipitación en información sobre periodos húmedos. Se aplicó una cadena de Markov para estimar las probabilidades iniciales y condicionales de ocurrencia del periodo húmedo para cada retícula; asimismo, se analizó la distribución espaciotemporal de las probabilidades de ocurrencia de periodos húmedos. Los mapas de probabilidad lograron capturar de manera adecuada el escenario del monzón de verano en la región India, representando el inicio, la progresión y la retirada de la lluvia del monzón. Se observó una mayor probabilidad de periodos húmedos en la costa oeste y el noreste de la India, es decir, había un máximo de probabilidad inicial en estas regiones. Por su parte, las probabilidades más bajas se observaron al oeste de Rajasthan, en Gujarat y en el sur del país. Se utilizó un umbral de $80 \%$ de la máxima probabilidad inicial para estandarizar la información probabilística espacialmente variable, y se consideró como posible semana húmeda aquella con valores mayores al umbral. La duración del periodo húmedo probable más largo registró valores máximos a lo largo de la costa oeste y el noreste de la India, en tanto que valores mínimos se observaron en el oeste y sur de la India. El inicio y duración del periodo más largo de la probable semana húmeda puede utilizarse para la planeación de la agricultura de temporal, es decir, el inicio de la siembra, la selección de cultivos y variedades con base en la duración de su periodo de crecimiento, el periodo óptimo de cosecha para evitas los periodos húmedos, etc.
\end{abstract}

\begin{abstract}
The spatial analysis of the wet spell probability over the Indian region has been carried out using daily gridded $\left(0.5^{\circ} \times 0.5^{\circ}\right)$ rainfall data of 1971-2005 during the summer monsoon period, i.e. June-September. A threshold was applied to the weekly cumulative rainfall to convert the rainfall data into wet spell information. A Markov chain model was employed to estimate the initial and conditional probabilities of the wet spell for each grid and the spatio-temporal distribution of the wet spells probabilities was analyzed. The probability maps were able to capture the summer monsoon scenario over the Indian region, representing the onset, progression and withdrawal of monsoon rainfall. Higher wet spell probability was observed over the west coast and northeastern parts of India, i.e., the initial probability was maximum over these regions. However, lower probability values were observed in West Rajasthan, Gujarat and southern India. A threshold of $80 \%$ of the maximum initial probability was used to standardize the spatially-variable probability information, and a week with more than the threshold values was considered as a probable wet week. The duration of the
\end{abstract}


longest probable wet spell was highest along the west coast and in northeastern India, whereas it was lowest in western and southern India. The start and duration of the longest spell of the probable wet week can be used for rainfed-agricultural planning, i.e., the start of sowing/planting, selection of crops and varieties based on their length of growing period, optimum harvesting period to avoid wet spell, etc.

Keywords: Markov chain, wet spell probability, probable wet week, Indian summer monsoon, rainfall.

\section{Introduction}

The South Asian monsoon, in general, and the Indian monsoon, in particular, are two of the most important and influential phenomena of Earth's climate system (Garnett and Khandekar, 1992; Gadgil, 2006; Roy, 2017). Eighty percent of the annual rainfall over the Indian region is generally received during the summer monsoon period, i.e., June to September (Sahai et al., 2003). In tropical countries like India, rainfall is the main input for agricultural farming as $61.3 \%$ of the gross cropped area falls under rainfed agriculture (Bhakar et al., 2008). In spite of the rapid increase in irrigated areas during the last few decades, around $80 \%$ of the farmers still solely depend on the monsoon rainfall (Bhakar et al., 2008; BLS, 2010). The success of rainfed agriculture is mostly determined by the onset and withdrawal of monsoon rainfall. For example, the pre-monsoon showers are a prerequisite for preparation of agricultural lands and the planting of crops, whereas early withdrawal of monsoon rainfall may lead to yield reduction due to moisture stress during the grain filling stages (Dixit et al., 2005). Hence, any kind of alteration in the onset, withdrawal, breaks or extreme rainfall events of Indian summer monsoon during critical crop growth stages may lead to decrease in crop acreage and reduced crop production. The spatial and temporal distribution of rainfall and its changing pattern would have a direct impact on the cropland patterns and productivity (Kumar et al., 2010). The annual and seasonal rainfall analysis gives a general idea about the prevailing rainfall patterns in the region, whereas weekly rainfall analysis was found to be more useful for agricultural planning (Reddy et al., 2008). According to Reddy (1990), the information on onset and withdrawal of rainfall along with the duration and distribution of wet spells can provide deep insight into the rainfall variability and farm management options.
The probability analysis of summer monsoon rainfall, including dry and wet spells, is being studied at regional levels. In particular, the Markov chain models have been extensively utilized by many researchers to find the probability of wet/dry weeks using long-term rainfall data over different parts of India (Pandharinath, 1991; Singh and Ranada, 2009) as well as in different parts of the globe (Gringorten, 1966; Lohani and Logananathan, 1997; Wilks and Wilby, 1999; Paulo and Pereira, 2007). Markov chain models have also been widely used in the field of natural resources, climate sciences, economics, etc. for understanding and forecasting the stochastic characters of different systems (Liu et al., 2009). This process, named after the Russian mathematician Andrey Markov (Shannon, 1948), accounts for the transition of one state to another in the form of a chain. It works like a chain where the probability of the outcomes depends on the previous step(s), i.e., the probability of being dry (wet) on a particular day is based on whether it was dry (wet) on the previous days (Tettey et al., 2017). The major assumption of the Markov chain process is that it considers the two states, i.e., dry and wet spell, mutually exclusive and completely exhaustive. The seasonal and annual rainfall patterns along with their probability distribution have been employed by many researchers for rainfed agricultural planning, probable alteration in the cropping pattern, etc., towards optimized utilization of the rainfall pattern (Sharma et al., 1979; Prakash and Rao, 1986; Chattopadhyay and Ganesan, 1995; Sharma and Thakur, 1995; Agnihotri, 1999; Bhakar et al., 2008; Reddy et al., 2008).

In the present study, a high resolution $\left(0.5^{\circ} \times 0.5^{\circ}\right)$ gridded rainfall data for a period of 35 years was used to study the initial and conditional probability of wet spells over the entire Indian region. The initial wet spell probability was converted to probable wet week information, and its start date and duration of the longest consecutive probable wet weeks were analyzed for agricultural planning and management. 


\section{Methodology}

\subsection{Preparation of the gridded rainfall dataset} In the present study, the high-resolution daily gridded $\left(0.5^{\circ} \times 0.5^{\circ}\right)$ rainfall data over a 35 -yr period, generated by the India Meteorological Department (IMD) for the entire Indian subcontinent, was used. As any climatic study requires a minimum of 30-35 yrs of data, we used the datasets available for 1971-2005 in this study. Similar datasets have been successfully utilized by many researchers for studying trends and rainfall patterns over the Indian region (Srivastava et al., 2008; Dash et al., 2013; Pingale et al., 2014, 2016). The Indian mainland with 34 meteorological subdivisions is shown in Figure 1. One may refer to Rajeevan and Bhate (2009) for details of the generation of gridded rainfall data. The daily rainfall data during the monsoon period, i.e., June to September, was converted to weekly cumulative rainfall. The threshold of more than $20 \mathrm{~mm}$ rainfall was used to consider a week as a wet spell (Pandharinath, 1991; Reddy et al., 2008). According to Reddy (1990), a minimum of $3 \mathrm{~mm}$ rainfall is essential for crops to satisfy their water requirements during the growing season (Yemenu and Chemeda, 2010). A week which was not able to fulfill the wet spell criteria is designated as dry spell. The detail of the methodology is given in Figure 2.

\subsection{Wet spell probability using Markov chain analysis}

The weekly wet spell information for each grid during the study period (1971-2005) over the Indian mainland was analyzed. The probability distribution of a wet spell for each week was estimated using the Markov chain analysis. The details of the equations are given below:

$$
\text { Initial probability }=P_{W}=\frac{\begin{array}{c}
\text { Number of } \\
\text { wet weeks }\left(F_{W}\right)
\end{array}}{\begin{array}{c}
\text { Number of years } \\
\text { of data }(n)
\end{array}}
$$
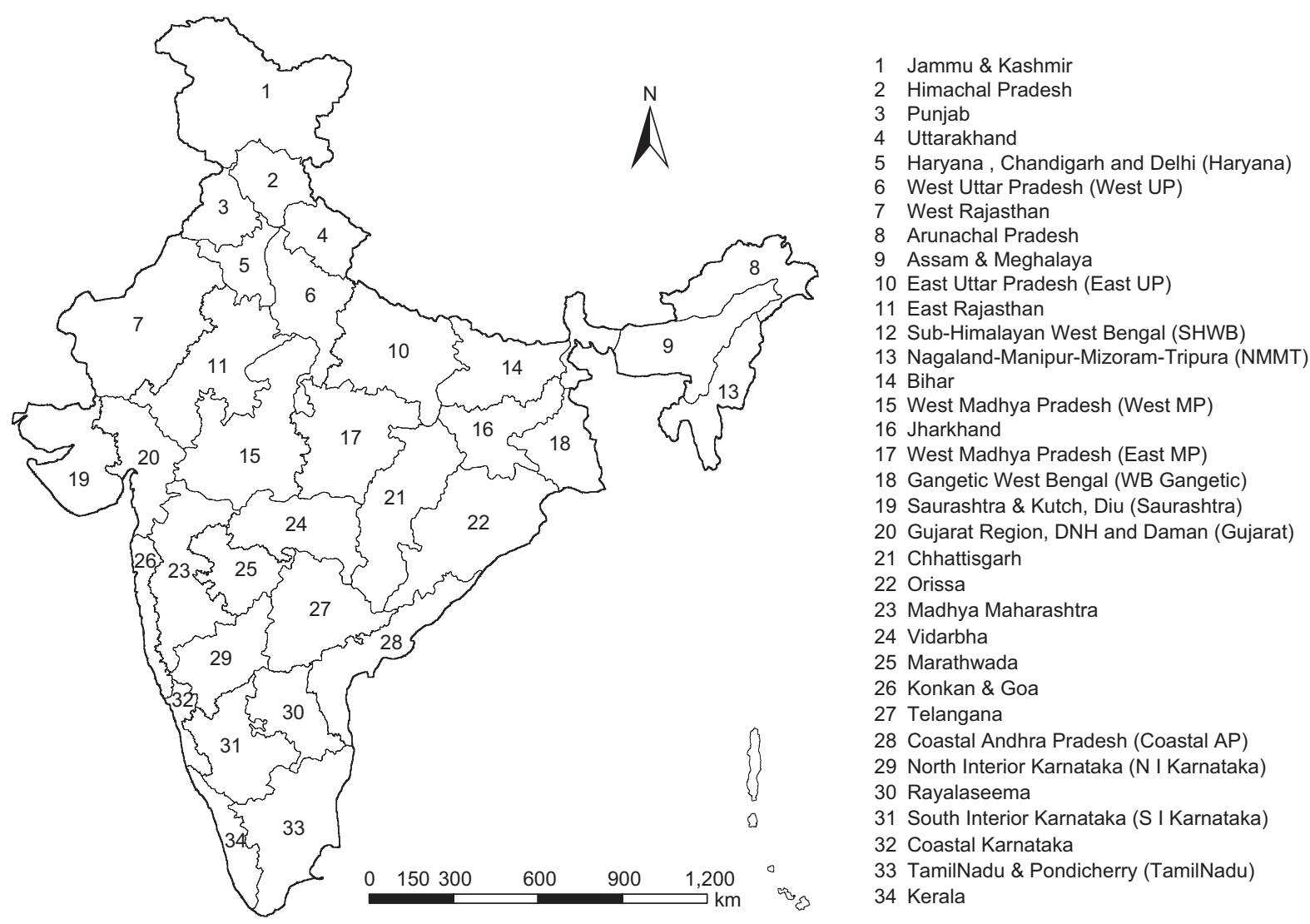

Fig. 1. Map of India with meteorological subdivisional boundaries. 


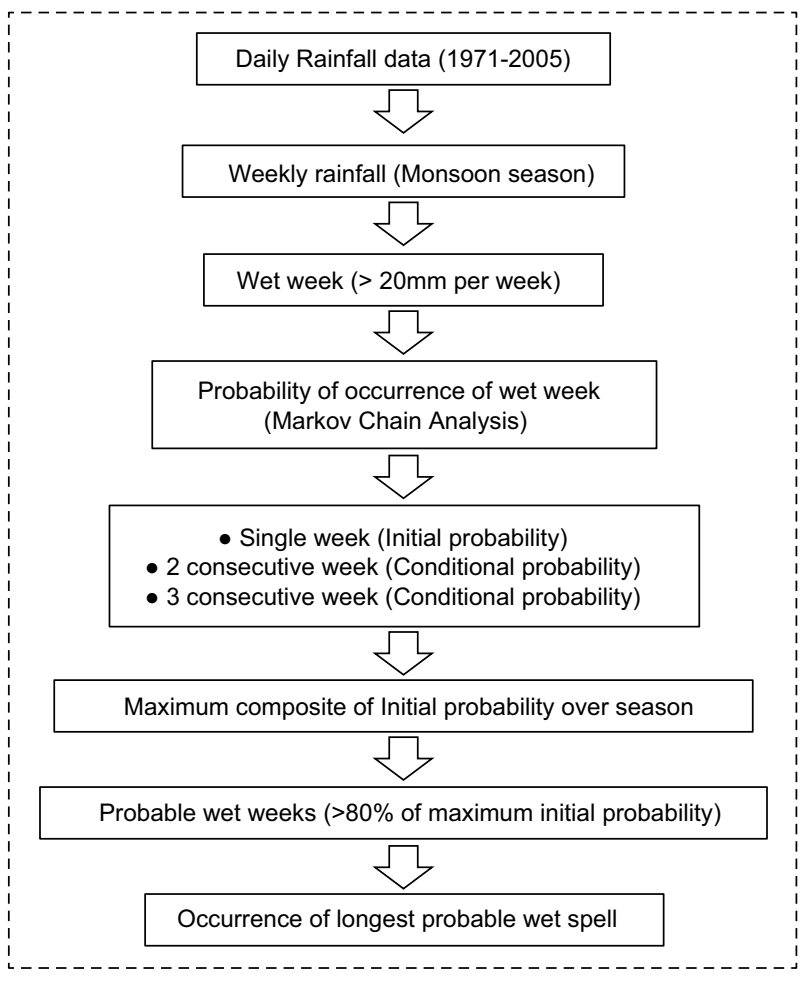

Fig. 2. Schematic diagram of the detailed methodology.

$$
\begin{aligned}
& \begin{array}{l}
\text { Nonditional } \\
\text { probability }=P_{W W}=\frac{\text { by another wet week }\left(F_{W W}\right)}{\text { Number of wet weeks }\left(F_{W}\right)}
\end{array}
\end{aligned}
$$

\section{Probability of two consecutive wet weeks} starting with the week $(2 \mathrm{~W})=P_{W W 1} \times P_{W W w 2}$

\section{Probability of three consecutive}

wet weeks starting with the week

$(3 \mathrm{~W})=P_{W w 1} \times P_{W W w 2} \times P_{W W w 3}$

where $\mathrm{P}_{\mathrm{Ww1}}$ is the probability of the week being wet (first week), i.e., the conditional probability of dry to wet week; $\mathrm{P}_{\mathrm{WWw} 2}$ is the probability of the second week being wet, given the preceding week wet, and $\mathrm{P}_{\mathrm{WWw} 3}$ is the probability of the third week being wet, given the preceding two wet weeks.

\subsection{Occurrence of the longest probable wet spell}

During the Indian monsoon season, the amount and distribution of rainfall varies from one region to another in the Indian subcontinent. For example, the south-east monsoon generally hits the northeastern part of India in the initial part of June and throughout the monsoon period it remains wet. On the other hand, the western part of India generally receives its first showers during mid-July only and remains wet for a very short period. Similarly, the maximum value of the wet spell probability along with its occurrence and duration of the longest wet spell was found to be varying at spatio-temporal scale, which is mainly attributed to the variations in the onset time of the monsoon. Hence, the longest wet spell information based on a fixed probability value cannot be used for all of India for agricultural planning.

In the present study, a novel approach was adopted to find out the longest probable wet weeks, which can be further utilized for agricultural planning by rainfall water management. The maximum wet spell probability layer was generated from the weekly wet spell probability maps by using the maximum compositing technique. The maximum composite approach was adopted to estimate the maximum possible wet spell probability for a given pixel/grid during the entire study period. It was assumed that a grid is considered to be probably wet for a given week if the probability value for a wet spell was more than $80 \%$ of the maximum wet spell probability. According to Gupta et al. (1975), the rainfall at $80 \%$ probability can be safely considered as assured rainfall, whereas $50 \%$ can be taken as the maximum limit for taking risks. Based on the above-mentioned criteria, the start and duration of the longest wet spell for each grid in India was generated, which can be utilized for efficient agricultural planning and determining the cropping pattern. The duration of the longest wet spell represents the number of continuous weeks that fulfill the above criteria, i.e., $80 \%$ of the maximum wet spell probability for a given grid, whereas the start of the longest wet spell is the starting week of the longest spell.

\section{Results and discussion}

\subsection{Initial wet spell probability}

The initial probability $\left(P_{\mathrm{W}}\right)$ of wet spell, derived from 35-yrs daily rainfall data using the Markov chain model, is shown in Fig. 3. It was observed that the spatio-temporal distribution of the wet spell 

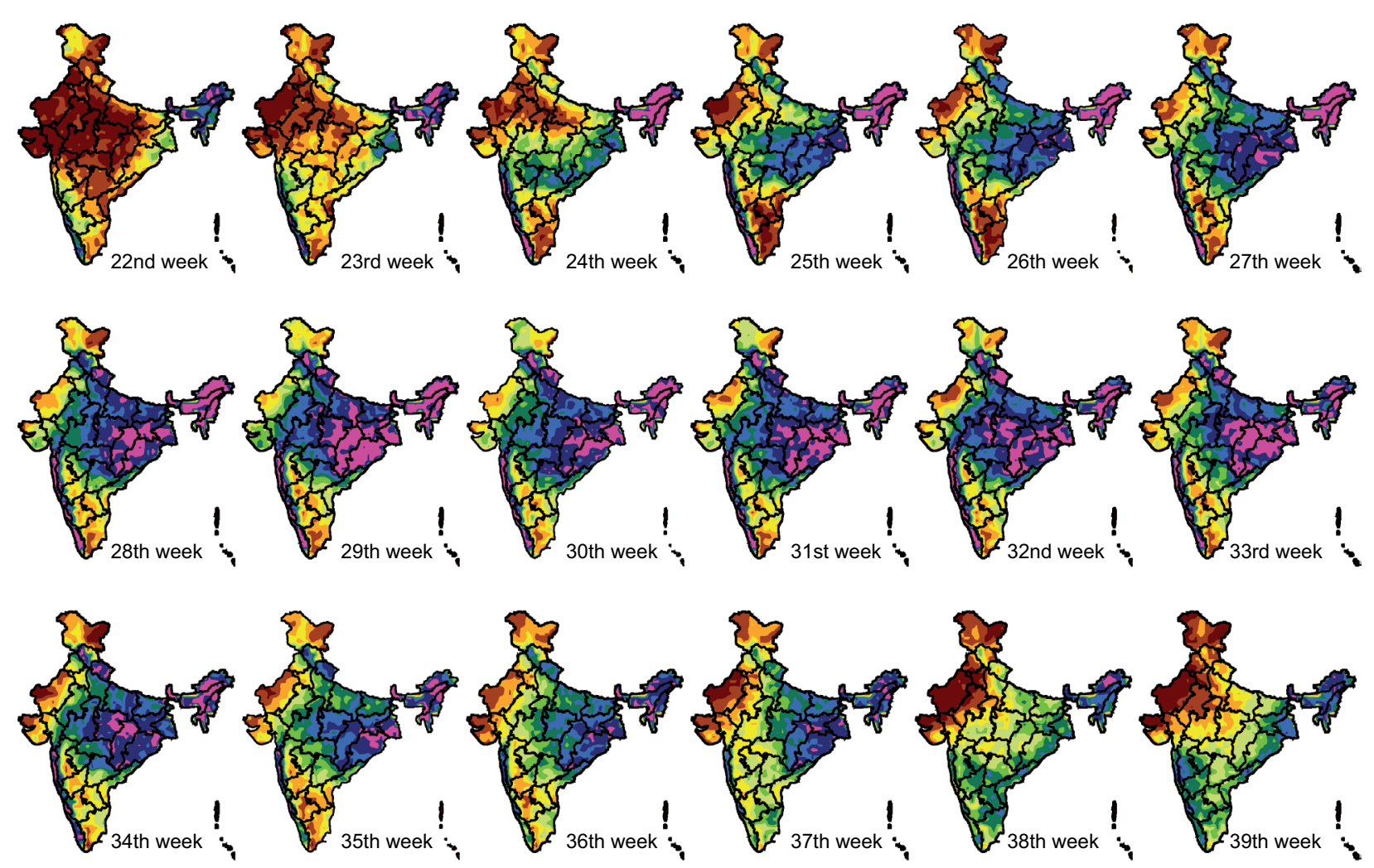

$0-0.1$ $0.1-0.2$ $0.2-0.3$ $0.3-0.4$ $0.4-0.5$ $0.5-0.6$ $0.6-0.7$ $0.7-0.8$ $0.8-0.9$ $0.9-1$

Fig. 3. Initial probability of wet spells based on Markov chain model (1971-2005) over India.

probability values represents the progress of the summer monsoon over the Indian region. At the start of June, the $P_{\mathrm{W}}$ of wet spell was more than $80 \%$ in Kerala, northeastern parts of India, sub-Himalayan West Bengal and coastal Karnataka. With the progress of the monsoon season, the higher probability values spread over the western coast and eastern India. At the end of June, the entire west coast and northeastern India; the eastern region covering the Gangetic West Bengal, Jharkhand, Orissa, Chhattisgarh and parts of East Madhya Pradesh, Bihar, Vidarbha; the northern region covering parts of east Uttar Pradesh, Uttarakhand, Himachal Pradesh, the $P_{\mathrm{W}}$ value was more than $80 \%$. Whereas a value of more than $70 \%$ was observed in Bihar, Uttar Pradesh, Madhya Pradesh, Vidarbha, Marathwada and some parts of Telangana and coastal Andhra Pradesh in southern India. During July, the entire central and northern India, covering Vidarbha, east and west Madhya Pradesh, east Rajasthan, east and west Uttar Pradesh, Himachal Pradesh, Uttarakhand and parts of Marathwada, Haryana, Punjab, along with the entire east and northeastern region, achieved high $P_{\mathrm{W}}$ values. During the 29th standard meteorological week (SMW) the overall $\mathrm{P}_{\mathrm{W}}$ was highest among all the SMW of the monsoon season, i.e., from the 22 nd to the 39 th week.

An almost static scenario between the 28th and 32nd SMW was observed. During these weeks, consistent high rainfall was received in most parts of the country, represented by the high wet spell probability values. Beyond mid-August, the withdrawal of the Indian summer monsoon (ISM) symptom was observed, represented by the decreasing values of $P_{\mathrm{W}}$ in the western and central parts of India. According to the Indian Meteorological Department (IMD), the withdrawal of the ISM starts around the September 1 over west Rajasthan, whereas it begins around 
October 1 over central India (https://www.tropmet.res.in/ kolli/MOL/Monsoon/year2016/Monsoon-2016.pdf). The withdrawal of the monsoon phenomenon is associated with enhanced convective activity along with the dry phase of the inter-seasonal oscillation. The dynamic and elongated low pressure zones build up over north-west India due to excessive solar radiation, generally known as monsoon trough, leads to remarkable alterations in the rainfall pattern (Syroka and Toumi, 2004).

The spatial as well as interannual variability of the ISM withdrawal was found to be higher than its onset (Syroka nad Toumi, 2004), and similar information was successfully utilized for studying rainfall variability, water resource management, relationship with crop harvest, spread of malaria, etc. (Das, 1987; Mooley and Shukla 1987; Rupa Kumar et al., 1992; Bouma and Van der Kaay, 1996). It is interesting to note that except for parts of Telangana, coastal Andhra Pradesh, northern Tamil Nadu and south interior Karnataka, almost the entire southern India could hardly achieve wet spell probability values of more than $40 \%$ up to the 34th SMW, i.e., the last week of July. Beyond this week, the $P_{\mathrm{W}}$ was increased in this region, whereas in the rest of India the probability started decreasing. This may be attributed to the withdrawal of monsoon rainfall from most of India and the commencement of north-east monsoon in southern India. The observations related to the onset, progression and withdrawal of summer monsoon over the Indian region have been reported by many researchers (Mooley and Shukla, 1987; Ananthakrishna and Soman, 1988; Despande and Singh, 2010).

\subsection{Conditional probability of wet spell for conse- cutive weeks}

The conditional probabilities of two and three consecutive wet weeks ( $2 \mathrm{~W}$ and $3 \mathrm{~W}$, respectively) starting with the 22nd week on all India, are shown in Figures 4 and 5 , respectively. During the initiation of the monsoon season, i.e., 22nd-23rd SMW, almost the entire Indian region except the western and northeastern parts, showed low probability $(<60 \%)$ for two consecutive wet spells. With the progress of the monsoon season, the $2 \mathrm{~W}$ started increasing. The pattern of increase in the $2 \mathrm{~W}$ followed the similar pattern of the $P_{\mathrm{W}}$, but the values, in terms of conditional probability, are lower than initial probability. The overall highest $2 \mathrm{~W}$ values were observed during the 29th week, when in most the parts of India the values were more than $60 \%$ with some patches of more than $80 \%$ over the northeast, east and central India. The $2 \mathrm{~W}$ values remained below $20 \%$ up to the 33 rd SMW in most parts of southern India, representing a very low probability of two consecutive wet spells. Similar to the $P_{\mathrm{W}}$, the values of $2 \mathrm{~W}$ in southern India started increasing beyond the 35th SMW, i.e., during mid-September. The start of the monsoon withdrawal symptoms was also captured by the decreasing values of $2 \mathrm{~W}$ beyond the $33 \mathrm{rd}$ week almost over all India. It was interesting to note that in the entire west Rajasthan and Gujarat region, the $2 \mathrm{~W}$ values could reach more than $20 \%$ throughout the monsoon season, depicting very low chances of getting persistence wet spells.

On the contrary, in the west coast and northeastern parts of India, very high $2 \mathrm{~W}$ values $(>80 \%)$ were observed throughout the monsoon season. Low probability values in western India may lead to insufficient water supply for agricultural needs, whereas persistent rainfall in the northeast of the country may result in flood-like situations.

During the initial part of the monsoon season, the probability of wetness for three consecutive weeks was found to be much less in most of India, except the western coast and northeastern parts of the country. The values of $3 \mathrm{~W}$ were more than $70 \%$ in the above mentioned regions, whereas the values were $<10 \%$ in the rest of country, except parts of west Bengal and Orissa (with $3 \mathrm{~W}$ values around 30 to $40 \%$ ). The probability values remained high throughout the monsoon season in the northeastern meteorological subdivisions of India, whereas the values remained lower than $10 \%$ in regions covering west Rajasthan, Gujarat, Madhya Maharashtra, north and south interior Karnataka, Rayalseema, Tamil Nadu. Similar to the $P_{\mathrm{W}}$, and $2 \mathrm{~W}$, the wet spell probability of three consecutive weeks also showed the progress of the monsoon in the Indian mainland. The highest $3 \mathrm{~W}$ values were found during the 29th SMW, whereas beyond the 33rd week a clear monsoon withdrawal symptom was observed in most parts of India. Unlike the rest of India, in the southern parts of the country, specifically Tamil Nadu and parts of Andhra Pradesh and Karnataka, the northeastern monsoon plays a major role along with the southwestern monsoon rainfall. The northeastern monsoon over south India could 

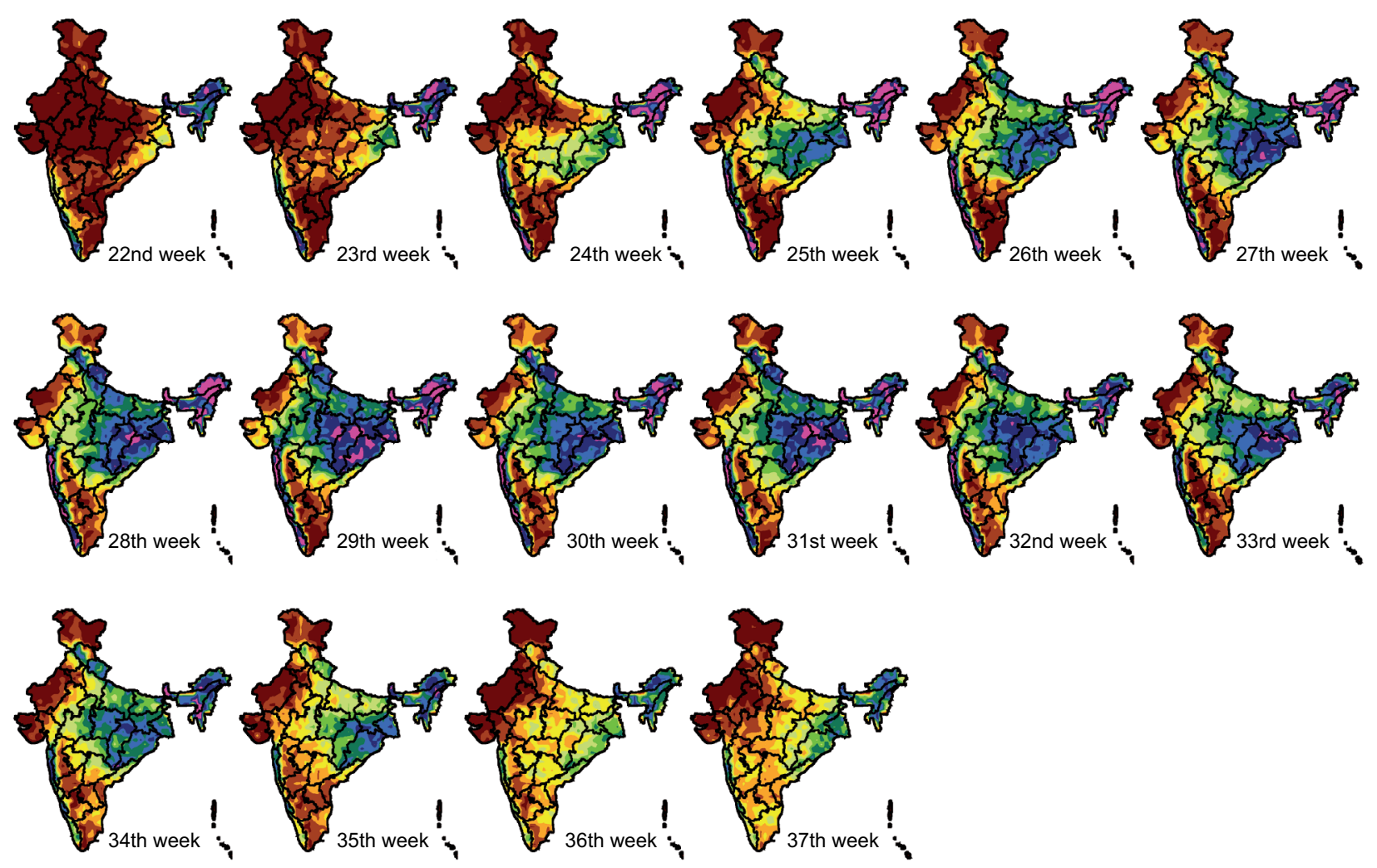

$0-0$. $0.1-0.2$

$0.2-0.3$

$0.3-0.4$

$0.4-0.5$

$0.5-0.6$

$0.6-0.7$

$0.7-0.8$

$0.8-0.9$

$0.9-1$

Fig. 4. Probability of two consecutive wet weeks starting on a week based on the Markov chain model (1971-2005).
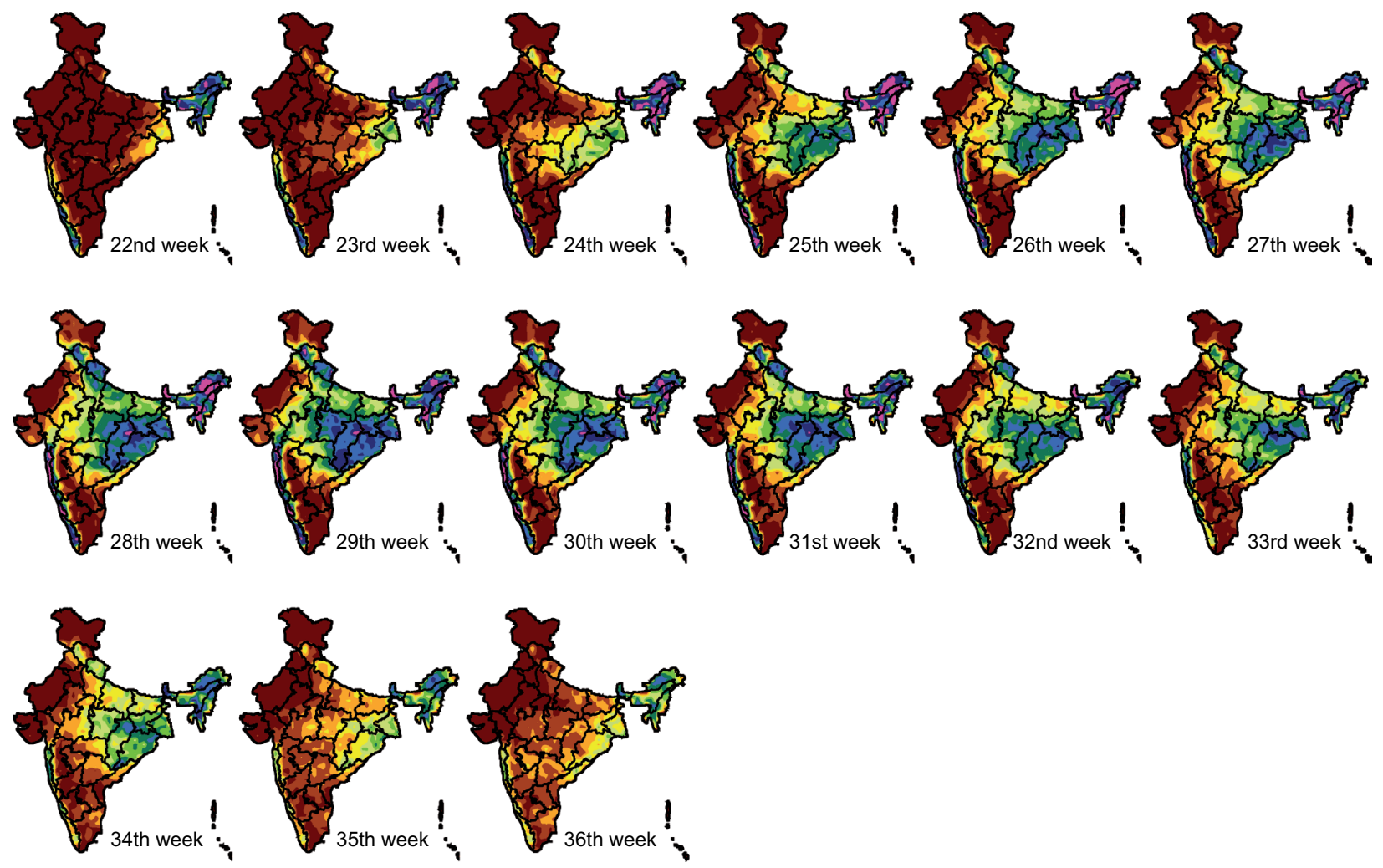

$0-0.1$

$0.1-0.2$

$0.2-0.3$

$0.3-0.4$

$0.4-0.5$

$0.5-0.6$

$0.6-0.7$

$0.7-0.8$

$0.8-0.9$

$0.9-1$

Fig. 5. Probability of three consecutive wet weeks starting on a week based on the Markov chain Model (1971-2005). 
be captured by the $\mathrm{P}_{\mathrm{w}}$, however it was not observed in $2 \mathrm{~W}$ and $3 \mathrm{~W}$. This may be due to the fact that the northeastern monsoon generally occurs beyond October, which is facilitated by the withdrawal of the southwestern monsoon.
The subdivision-wise mean wetness probability for $3 \mathrm{~W}$ is shown in Table I. As discussed earlier, the distribution of the $3 \mathrm{~W}$ varied spatially as well as temporally. The longest wet spell with considerable $3 \mathrm{~W}$ values $(>60 \%)$ was observed over the Assam

Table I. Meteorological subdivision-wise condition probability for three consecutive wet weeks during each week of the monsoon period.

\begin{tabular}{|c|c|c|c|c|c|c|c|c|c|c|c|c|c|c|c|}
\hline $\begin{array}{l}\text { Meteorological } \\
\text { subdivisions }\end{array}$ & 22nd & $23 \mathrm{rd}$ & 24 th & 25 th & 26th & 27 th & 28th & 29th & 30th & $31 \mathrm{st}$ & $32 \mathrm{nd}$ & $33 \mathrm{rd}$ & 34 th & 35 th & 36 th \\
\hline \multicolumn{16}{|l|}{ Jammu and } \\
\hline Kashmir & 0.02 & 0.02 & 0.03 & 0.06 & 0.07 & 0.09 & 0.10 & 0.10 & 0.07 & 0.05 & 0.06 & 0.06 & 0.04 & 0.02 & 0.01 \\
\hline Himachal Pradesh & 0.05 & 0.10 & 0.19 & 0.29 & 0.34 & 0.41 & 0.47 & 0.48 & 0.47 & 0.40 & 0.37 & 0.32 & 0.23 & 0.15 & 0.09 \\
\hline Punjab & 0.02 & 0.05 & 0.15 & 0.25 & 0.35 & 0.42 & 0.43 & 0.46 & 0.42 & 0.40 & 0.34 & 0.29 & 0.23 & 0.09 & 0.04 \\
\hline Uttarakhand & 0.09 & 0.22 & 0.23 & 0.40 & 0.52 & 0.58 & 0.61 & 0.64 & 0.64 & 0.60 & 0.57 & 0.49 & 0.40 & 0.25 & 0.16 \\
\hline Haryana & 0.02 & 0.04 & 0.07 & 0.15 & 0.19 & 0.27 & 0.28 & 0.29 & 0.27 & 0.25 & 0.18 & 0.19 & 0.12 & 0.05 & 0.04 \\
\hline West UP & 0.03 & 0.09 & 0.15 & 0.28 & 0.43 & 0.45 & 0.59 & 0.55 & 0.55 & 0.50 & 0.41 & 0.36 & 0.30 & 0.15 & 0.11 \\
\hline West Rajasthan & 0.00 & 0.00 & 0.00 & 0.01 & 0.03 & 0.05 & 0.04 & 0.05 & 0.05 & 0.03 & 0.04 & 0.03 & 0.02 & 0.01 & 0.00 \\
\hline \multicolumn{16}{|l|}{ Arunachal } \\
\hline Pradesh & 0.48 & 0.51 & 0.52 & 0.56 & 0.54 & 0.54 & 0.51 & 0.46 & 0.46 & 0.42 & 0.38 & 0.39 & 0.40 & 0.36 & 0.37 \\
\hline \multicolumn{16}{|c|}{ 然 } \\
\hline Meghalaya & 0.68 & 0.70 & 0.75 & 0.76 & 0.76 & 0.74 & 0.72 & 0.69 & 0.66 & 0.67 & 0.63 & 0.61 & 0.60 & 0.53 & 0.50 \\
\hline East UP & 0.04 & 0.13 & 0.17 & 0.33 & 0.51 & 0.49 & 0.56 & 0.55 & 0.53 & 0.53 & 0.40 & 0.41 & 0.39 & 0.21 & 0.15 \\
\hline East Rajasthan & 0.00 & 0.02 & 0.05 & 0.11 & 0.21 & 0.21 & 0.29 & 0.33 & 0.24 & 0.23 & 0.24 & 0.18 & 0.11 & 0.05 & 0.04 \\
\hline SHWB & 0.48 & 0.50 & 0.52 & 0.55 & 0.55 & 0.55 & 0.54 & 0.52 & 0.51 & 0.52 & 0.50 & 0.48 & 0.46 & 0.42 & 0.39 \\
\hline NMMT & 0.49 & 0.54 & 0.59 & 0.59 & 0.58 & 0.58 & 0.56 & 0.56 & 0.52 & 0.52 & 0.51 & 0.48 & 0.45 & 0.39 & 0.36 \\
\hline Bihar & 0.16 & 0.25 & 0.31 & 0.45 & 0.56 & 0.57 & 0.56 & 0.56 & 0.53 & 0.53 & 0.43 & 0.43 & 0.45 & 0.30 & 0.24 \\
\hline West MP & 0.01 & 0.07 & 0.15 & 0.25 & 0.34 & 0.37 & 0.42 & 0.54 & 0.44 & 0.40 & 0.45 & 0.37 & 0.26 & 0.17 & 0.10 \\
\hline Jharkhand & 0.12 & 0.25 & 0.34 & 0.51 & 0.62 & 0.58 & 0.63 & 0.64 & 0.64 & 0.64 & 0.52 & 0.53 & 0.53 & 0.34 & 0.27 \\
\hline East MP & 0.02 & 0.11 & 0.20 & 0.45 & 0.52 & 0.55 & 0.60 & 0.70 & 0.62 & 0.65 & 0.61 & 0.55 & 0.45 & 0.23 & 0.15 \\
\hline Ganeetic WB & 0.24 & 0.41 & 0.42 & 0.54 & 0.58 & 0.59 & 0.61 & 0.62 & 0.60 & 0.55 & 0.51 & 0.54 & 0.45 & 0.38 & 0.33 \\
\hline Saurashtra & 0.00 & 0.02 & 0.03 & 0.06 & 0.08 & 0.09 & 0.08 & 0.10 & 0.06 & 0.03 & 0.02 & 0.02 & 0.02 & 0.02 & 0.02 \\
\hline Gujarat & 0.01 & 0.03 & 0.08 & 0.14 & 0.22 & 0.22 & 0.26 & 0.32 & 0.22 & 0.19 & 0.19 & 0.14 & 0.11 & 0.07 & 0.06 \\
\hline Chhattisgarh & 0.06 & 0.17 & 0.36 & 0.62 & 0.70 & 0.73 & 0.76 & 0.79 & 0.74 & 0.77 & 0.67 & 0.62 & 0.57 & 0.33 & 0.20 \\
\hline Orissa & 0.19 & 0.29 & 0.46 & 0.60 & 0.65 & 0.69 & 0.70 & 0.73 & 0.69 & 0.68 & 0.66 & 0.64 & 0.56 & 0.40 & 0.30 \\
\hline \multicolumn{16}{|l|}{ Madhya } \\
\hline Maharashtrata & 0.07 & 0.11 & 0.18 & 0.22 & 0.30 & 0.28 & 0.31 & 0.37 & 0.31 & 0.25 & 0.27 & 0.19 & 0.14 & 0.13 & 0.15 \\
\hline Vidarbha & .04 & 0.14 & 0.32 & 0.43 & 0.50 & 0.48 & 0.52 & 0.56 & 0.51 & 0.49 & 0.47 & 0.38 & 0.32 & 0.21 & 0.18 \\
\hline Marathwada & 0.05 & 0.08 & 0.15 & 0.18 & 0.20 & 0.21 & 0.24 & 0.23 & 0.22 & 0.19 & 0.21 & 0.15 & 0.14 & 0.16 & 0.20 \\
\hline Konkan and Goa & 0.26 & 0.44 & 0.63 & 0.69 & 0.74 & 0.75 & 0.77 & 0.77 & 0.76 & 0.73 & 0.68 & 0.60 & 0.48 & 0.36 & 0.39 \\
\hline Telangana & 0.06 & 0.10 & 0.26 & 0.35 & 0.36 & 0.45 & 0.51 & 0.46 & 0.46 & 0.41 & 0.39 & 0.30 & 0.23 & 0.19 & 0.20 \\
\hline Coastal AP & 0.06 & 0.07 & 0.16 & 0.18 & 0.19 & 0.30 & 0.29 & 0.29 & 0.30 & 0.28 & 0.24 & 0.24 & 0.22 & 0.20 & 0.24 \\
\hline NI Karnataka & 0.07 & 0.09 & 0.14 & 0.14 & 0.14 & 0.16 & 0.20 & 0.18 & 0.19 & 0.14 & 0.11 & 0.11 & 0.13 & 0.15 & 0.19 \\
\hline Rayalaseema & 0.02 & 0.02 & 0.06 & 0.07 & 0.08 & 0.12 & 0.13 & 0.11 & 0.12 & 0.13 & 0.11 & 0.11 & 0.12 & 0.14 & 0.15 \\
\hline SI Karnataka & 0.05 & 0.04 & 0.07 & 0.09 & 0.08 & 0.10 & 0.12 & 0.11 & 0.13 & 0.14 & 0.07 & 0.05 & 0.09 & 0.09 & 0.12 \\
\hline Coastal Karnataka & 0.49 & 0.61 & 0.70 & 0.72 & 0.73 & 0.71 & 0.73 & 0.75 & 0.73 & 0.68 & 0.60 & 0.46 & 0.35 & 0.28 & 0.30 \\
\hline TamilNadu & 0.04 & 0.04 & 0.04 & 0.03 & 0.04 & 0.06 & 0.07 & 0.05 & 0.08 & 0.08 & 0.07 & 0.07 & 0.13 & 0.11 & 0.15 \\
\hline Kerala & 0.52 & 0.57 & 0.62 & 0.62 & 0.61 & 0.58 & 0.60 & 0.61 & 0.56 & 0.55 & 0.45 & 0.32 & 0.27 & 0.25 & 0.27 \\
\hline
\end{tabular}

$3 \mathrm{~W}>50 \%$ are shown in grey; $3 \mathrm{~W}>75 \%$ in bold characters. 
and Meghalaya subdivision, followed by Konkan and Goa. Whereas, very low $3 \mathrm{~W}$ values $(<25 \%)$ were found in subdivisions like Saurashtra, Gujarat, south and north interior Karnataka and Rayalseema, denoting very low rainfall regimes not suitable for rain-fed agriculture. The subdivisions including Nagaland-Manipur-Mizoram-Tripura (NMMT), the sub-Himalayan West Bengal, Chhattisgarh, Orissa, Jharkhand, Gangetic West Bengal and coastal Karnataka showed an intermediate level of $3 \mathrm{~W}$ values (40 to 60\%) with moderate persistence, representing a favorable rainfall distribution for rain-fed agricultural activities. The highest values of $3 \mathrm{~W}$ during the monsoon season varied from one meteorological subdivision to another. For example, in Assam and Meghalaya the highest value was 0.76 , whereas it was 0.79 in Chhattisgarh with less persistent wet spells. Similarly, in the case of Saurashtra the highest 3W value was less than $10 \%$ during the whole monsoon and around $20 \%$ over north interior Karnataka. Hence, the maximum values of wet spell probability and its persistency was found to vary from one meteorological subdivision to another. Dry and wet spells largely depend on the monsoon depression over the Bay of Bengal. Recently, Midya et al. (2019) reported that a variation of meridional SST gradient during pre-monsoon months and the frequency of the northwest Pacific weather system (number of typhoons and super typhoons) during monsoon months may be possible causes of change of the monsoon depression over the Bay of Bengal. Moreover, the association by El-Niño events and deficiency of rainfall is also reported by different scientists throughout the world. The spatial variations in wind patterns, amount of water vapor, presence of cloud condensation nuclei, etc., may be some of the governing factors along with orographic effect towards variations and persistency of wet spells across different parts of India. Recent studies showed that condensation cannot start without cloud condensation nuclei $(\mathrm{CCN})$ of proper dimension. The biogenic volatile organic compounds (BVOC) emitted by forest zones act as $\mathrm{CCN}$, which affects the rainfall patterns in those forests (Midya et al., 2015). On the other hand, Ganda et al. (2012) reported that rainfall in urban areas gradually increases with respect to non-urban belts. It is concluded that anthropogenic volatile compounds (AVOC) produced due to vehicular pollution, urban heat island, etc., may be the cause of the increase in rainfall patterns over the urban region.

\subsection{Start and duration of the longest probable wet weeks}

In the present study, a threshold approach (i.e., $80 \%$ of the maximum initial probability) has been adopted to standardize the effect of spatial variability. A week was designated as probable wet week if the initial probability of the week was more than $80 \%$ of the maximum $P_{\mathrm{W}}$ for a given pixel. For example, the values for a week to be considered as probable wet week should be 0.72 and 0.40 for pixels with maximum initial probability of $90 \%$ and $50 \%$, respectively. Hence, the above-mentioned threshold was utilized to calculate the maximum probability of occurrence of a wet week, the total duration of the longest probable consecutive wet weeks and its starting week. The span of the longest probable wet weeks can be used for improved rain-fed agricultural planning, i.e., time of sowing/planting, selection of crops and varieties based on their length of growing period, harvesting of the crops to avoid wet weeks, etc.

The details of the maximum probability for occurrence of a wet week, duration and start week of the longest probable wet weeks over the Indian region is given in Figure 6. It was observed that in all northeastern India and the western coast, along with West Bengal, Bihar, Orissa, Jharkhand, Chhattisgarh, Uttarakhand, Madhya Pradesh, Uttar Pradesh and parts of Himachal Pradesh, Telangana, Coastal Andhra Pradesh and Vidarbha, the maximum probability was more than $80 \%$, whereas lower values $(<50 \%)$ were observed in the entire Jammu and Kashmir, West Rajasthan, Haryana, and parts of Tamil Nadu and Punjab (Fig. 6a). In the rest of the regions, the maximum wet spell probability varied from 50 to $80 \%$. Figure $6 \mathrm{~b}$ represents the duration of the longest probable wet weeks derived from the initial probability and proposed thresholds. The duration was almost more than 15 consecutive weeks in northeastern parts of India, whereas it was around 13 consecutive weeks in the entire western coast. The values of longest probable wet weeks were around 11 to 14 in West Bengal, whereas in most parts of Jharkhand, Bihar, Chhattisgarh, Orissa and Uttarakhand the values were between 9 and 12. The lowest values ( 7 to 10 

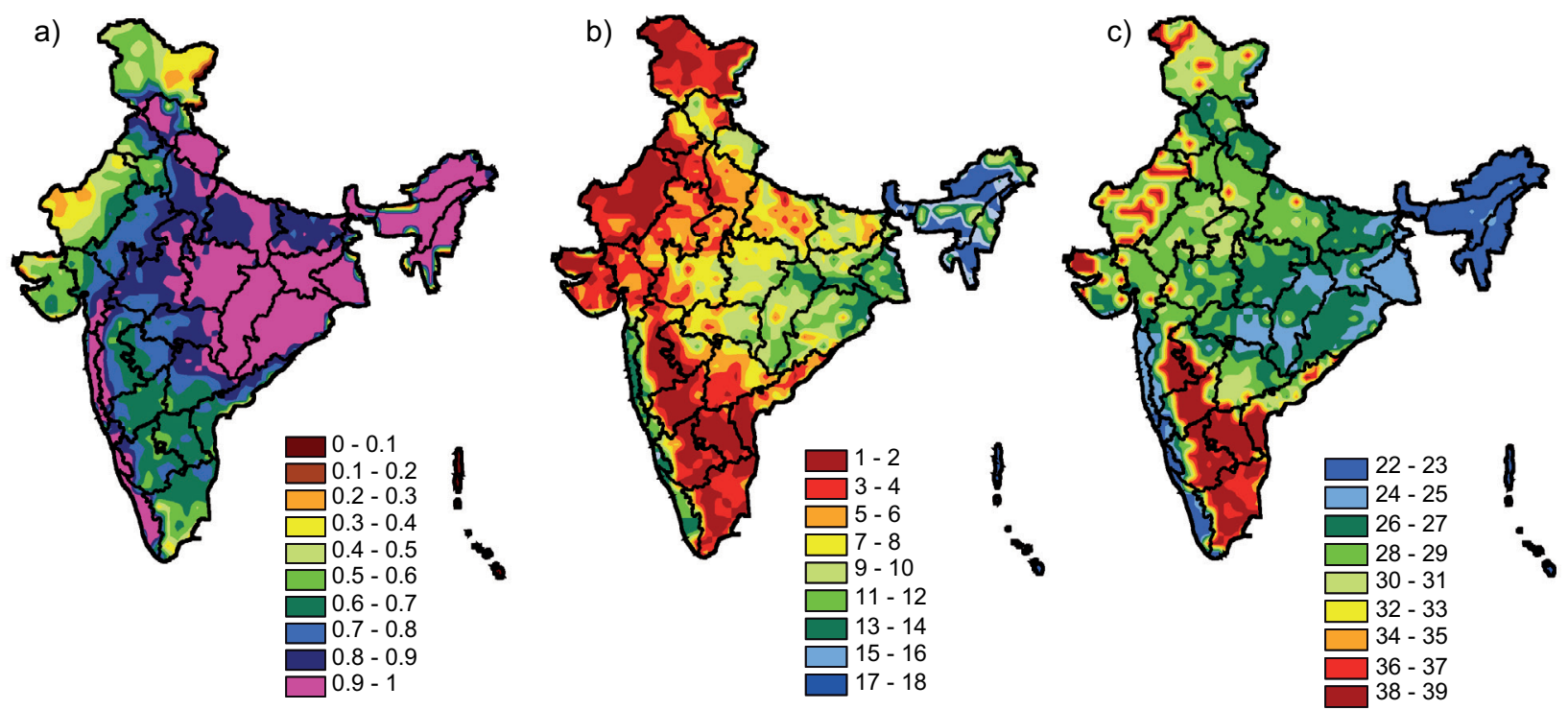

Fig. 6. Contour maps showing (a) maximum probability of occurrence of a wet week, (b) duration and (c) start week of longest probable consecutive wet weeks.

for the longest consecutive probable wet weeks) were observed in parts of Vidarbha and Madhya Pradesh.

In the rest of the Indian region, the overall duration of the longest consecutive probable wet weeks was less than five, whereas in West Rajasthan, Gujarat, Madhya Maharashtra, Rayalseema, North Interior Karnatak and parts of South Interior Karnataka, Tamil Nadu and coastal Andhra Pradesh, the values were even less than two, representing either very low probability of wet spell or irregular temporal distribution of rainfall. Similarly, the start week of the longest consecutive probable wet weeks for different regions of India is given in Figure 6c. The longest consecutive probable wet weeks for most parts of northeastern India, the west coast, West Bengal and parts of Orissa, Jharkhand, Chhattisgarh and Vidarbha, generally occurred during the first fortnight of June, whereas in Uttar Pradesh, Madhya Pradesh, Haryana, Himachal Pradesh, Uttarakhand, east Rajasthan and parts of Gujarat and Telangana, this occurred in the second fortnight of June. In southern India, consisting of Tamil Nadu, Rayalseema, North and South Interior Karnataka, Madhya Maharashtra and parts of coastal Andhra Pradesh, along with parts of Gujarat and West Rajasthan, the longest spell of probable wet weeks generally started in the second fortnight of September.

In southern India, the delay may be due to the dominance of the north-east monsoon, whereas in
Gujarat and West Rajasthan it might be attributed to the delayed arrival of the southwest monsoon rainfall. The meteorological subdivision-wise details of the longest consecutive probable wet weeks are given in Table II. The spatial variation in Indian summer monsoon is mainly attributed to the convection over the Bay of Bengal (Gadgil, 2003). According to Murakami (1976), consecutive wet spells result from the overlapping development of the propagation systems over the Bay of Bengal, however no such systems occur over the monsoon zone during breaks. Hence, the variations in the monsoon's date of arrival, the meteorological parameters, land use and land cover pattern may be driving factors for the spatial variations of the longest wet spells and their corresponding persistence period.

\section{Summary and conclusions}

In the present study, the spatial analysis of the wet spell probability was carried out using daily gridded rainfall data of a 35-yr period (1971-2005). The estimated initial probability could represent the probability of occurrence of a single wet spell, whereas conditional probability showed the probability of occurrence of two and three consecutive wet weeks. Based on the estimated wet spell probabilities, the rainfall regimes existing in the Indian 
Table II. Meteorological subdivision-wise probable wet week information.

\begin{tabular}{|c|c|c|c|c|c|}
\hline \multirow{2}{*}{$\begin{array}{l}\text { Meteorological } \\
\text { subdivisions }\end{array}$} & \multirow{2}{*}{$\begin{array}{l}\text { Maximum } \\
\text { probability }\end{array}$} & \multicolumn{4}{|c|}{ Longest probable consecutive wet weeks } \\
\hline & & Threshold & Start week & End week & Duration (days) \\
\hline Jammu and Kashmir & 0.47 & 0.38 & 30 & 35 & 32 \\
\hline Himachal Pradesh & 0.77 & 0.62 & 27 & 34 & 49 \\
\hline Punjab & 0.82 & 0.66 & 28 & 35 & 52 \\
\hline Uttarakhand & 0.89 & 0.71 & 26 & 36 & 69 \\
\hline Haryana & 0.68 & 0.55 & 28 & 33 & 33 \\
\hline West UP & 0.87 & 0.69 & 28 & 34 & 41 \\
\hline West Rajasthan & 0.41 & 033 & 32 & 34 & 16 \\
\hline Arunachal Pradesh & 0.85 & 0.68 & 22 & 36 & 96 \\
\hline Assam and Meghalaya & 0.99 & 0.79 & 22 & 38 & 113 \\
\hline East UP & 0.89 & 0.72 & 28 & 35 & 49 \\
\hline East Rajasthan & 0.69 & 0.55 & 29 & 33 & 27 \\
\hline SHWB & 0.99 & 0.80 & 22 & 39 & 120 \\
\hline NMMT & 0.95 & 0.76 & 22 & 38 & 110 \\
\hline Bihar & 0.88 & 0.70 & 26 & 35 & 65 \\
\hline West MP & 0.85 & 0.68 & 29 & 35 & 40 \\
\hline Jharkhand & 0.91 & 0.73 & 27 & 35 & 62 \\
\hline East MP & 0.92 & 0.74 & 28 & 36 & 56 \\
\hline Gangetic WB & 0.94 & 0.75 & 24 & 37 & 89 \\
\hline Saurashtra & 0.52 & 0.42 & 30 & 36 & 42 \\
\hline Gujarat & 0.67 & 0.54 & 30 & 34 & 28 \\
\hline Chhattisgarh & 0.96 & 0.77 & 26 & 36 & 70 \\
\hline Orissa & 0.96 & 0.77 & 26 & 37 & 79 \\
\hline Madhya Maharashtra & 0.77 & 0.62 & 31 & 34 & 25 \\
\hline Vidarbha & 0.86 & 0.69 & 26 & 35 & 60 \\
\hline Marathwada & 0.70 & 0.56 & 32 & 37 & 34 \\
\hline Konkan and Goa & 1.00 & 0.80 & 24 & 37 & 95 \\
\hline Telangana & 0.84 & 0.67 & 28 & 34 & 44 \\
\hline Coastal AP & 0.75 & 0.60 & 31 & 37 & 40 \\
\hline NI Karnataka & 0.70 & 0.56 & 34 & 37 & 25 \\
\hline Rayalaseema & 0.65 & 0.52 & 37 & 39 & 15 \\
\hline S.I. Karnataka & 0.64 & 0.52 & 37 & 39 & 18 \\
\hline Coastal Karnataka & 0.84 & 0.67 & 23 & 35 & 82 \\
\hline Tamil Nadu & 0.61 & 0.48 & 37 & 39 & 20 \\
\hline Kerala & 0.88 & 0.70 & 26 & 36 & 70 \\
\hline India & 0.80 & 0.64 & 28 & 36 & 55 \\
\hline
\end{tabular}

region can be captured. Higher wet spell probability was observed over the west coast and northeastern parts of India during the first week of June. The wet spell probability increased in the subsequent weeks as the monsoon progressed from eastern to central India, followed by northern and western parts of the country. The overall highest probability of wet spell was observed during the second fortnight of July. The withdrawal of monsoon symptoms during the first week of September were captured by decreasing probability values, whereas the increasing wet spell probability over southern India represented the initiation of northeastern monsoon rainfall. A new approach, probable wet weeks, was proposed and the start and duration of the longest probable wet weeks were calculated. The duration of the longest spell of consecutive probable wet weeks was observed in the west coast, northeast and eastern parts of India, whereas the lowest was found over the western and southern regions. The new approach could normalize the spatial variability and can be used for better agricultural planning and management. 


\section{Acknowledgements}

We express our sincere thanks to Dr. Santanu Choudhury, Director, National Remote Sensing Centre, for his constant encouragement and suggestions. IMD is duly acknowledged for providing gridded rainfall data. The authors are also grateful to the editors and anonymous reviewers for their constructive suggestions.

\section{References}

Agnihotri Y. 1999. Trends analysis of short-term seasonal rainfall and crop planting in Shivalik Foothill region. Indian Journal of Soil Conservation 27: 64-69.

Ananthakrishnan R, Soman MK. 1988. Onset of southwest monsoon over Kerala, 1901-1980. Journal of Climate 8: 283-296. DOI: 10.1002/joc.3370080305

Bhakar SR, Iqbal M, Devanda M, Chhajed N, Bansal A. 2008. Probability analysis of rainfall at Kota. Indian Journal of Agricultural Research 42: 201-206.

Bouma MJ, van der Kaay HJ. 1996. The El Niño Southern Oscillation and the historic malaria epidemics on the Indian subcontinent and Srilanka: An early warning system for future epidemics? Tropical Medicine and International Health 1: 86-96. DOI: 10.1046/j.13653156.1996.d01-7.x

BLS. 2010. Report on employment and unemployment survey (2009-10). Bureau of Labour Statistics, Government of India, Chandigarh. Available at: http://labourbureau. nic.in/Final_Report_Emp_Unemp_2009-10.pdf

Chattopadhaya N, Ganesan GS. 1995. Relative contribution of energy and aerodynamic terms to potential evapotranspiration at Madras. Mausam 46: 263-274.

Das PK. 1987. Short and long range monsoon prediction in India. In: Monsoons (Fein JS, Stephens PL, Eds.). John Wiley and Sons, New York, pp. 549-578.

Dash SK, Saraswat V, Panda SK, Sharma N. 2013. A study of changes in rainfall and temperature patterns at four cities and corresponding meteorological subdivisions over coastal regions of India. Global and Planetary Change 108: 175-194.

DOI: 10.1016/j.gloplacha.2013.06.004

Despande NR, Singh N. 2010. Spatial and temporal variations in the occurrences of wet periods over major river basins in India. Journal of Earth System Science 119: 561-578.DOI: 10.1007/s12040-010-0048-z

Dixit AJ, Yadav ST, Kokate KD. 2005. The variability of rainfall in Konkan region. Journal of Agrometeorology 7: $322-324$.
Gadgil S. 2003. The Indian monsoon and its variability. $A n-$ nual Reviews of Earth and Planetary Science 31: 429467. DOI: 10.1146/annurev.earth.31.100901.141251

Gadgil S. 2006. The Indian monsoon - How do we get rain? Resonance: 8-21. DOI: 10.1007/BF02834470

Ganda SC, Midya SK. 2012. Comparison of long-term rainfall trends on urban and non-urban regions of Indian land mass and its probable implication. Journal of the Indian Geophysical Union 16: 37-40.

Garnett ER, Khandekar ML. 1992. The impact of largescale atmospheric circulations and anomalies on Indian monsoon and floods and on world grain yields-A statistical analysis. Agriculture and Forest Meteorology 61: 113-128. DOI: 10.1016/0168-1923(92)90028-3

Gringorten II. 1966. A stochastic model of the frequency and duration of weather events. Journal of Climate and Applied Meteorology 4: 606-624.

Gupta SK, Babu R, Tejwani KG. 1975. Weekly rainfall of India for planning cropping programme. Soil Conservation Digest 3: 31-39.

DOI: $10.1080 / 02626667.2010 .481373$

Kumar V, Sharad KJ, Yatveer S. 2010. Analysis of longterm rainfall trends in India. Hydrological Science Journal 55: 484-496.

Liu X, Ren L, Yuan F, Yang B, Nanjing PR. 2009. Meteorological drought forecasting using Markov Chain model. In: 11th International Conference on Environmental Science and Information Application Technology, Chania, Crete, Greece, pp. 23-26. Available at: http://toc.proceedings.com/18229webtoc.pdf

Lohani VK, Loganathan GV. 1997. An early warning system for drought management using Palmer drought index. Journal of American Water Resource Association 33: 1375-1386.

DOI: $10.1111 / \mathrm{j} .1752-1688.1997 . t b 03560 . x$

Meinke H. 2003. Options for cropping system management at a range of time scales. In: Science for drought. Proceedings of the National Drought Forum (Stone RC, Ed.), 82-87.

Midya SK, Ghosh S, Ganda SC, Das GK. 2015. Role of biogenic hydrocarbon on the variability of total rainfall amount over Sundarban, Kaziranga and Gir forests. Journal of the Indian Geophysical Union 19: 454-459.

Midya SK, Dey SS, Das A, Sutta S, Das GK. 2019. Role of premonsoon meridional SST gradient of north Indian ocean and frequency of typhoon activities on monsoon depression over Bay of Bengal. Indian Journal of Physics. DOI: 10.1007/s12648-019-01481-z 
Mooley DA, Shukla J. 1987. Variability and forecasting of the summer monsoon rainfall over India. In: Monsoon meteorology (Chang CP, Krinsmurti TN, Eds.). Oxford University Press, New York, 26-59.

Murakami T. 1976. Cloudiness fluctuations during the summer monsoon. Journal of the Meteorological Society of Japan 54: 175-181.

Pandharinath, N. 1991. Markov chain model probability of dry, wet weeks during monsoon period over Andhra Pradesh. Mausam 42: 393-400.

Paulo A, Pereira LS. 2007. Prediction of SPI drought class transitions using Markov chains. Water Resources Management 21: 1813-1827.

DOI: $10.1007 / \mathrm{s} 11269-006-9129-9$

Pingale SM, Khare D, Jat MK, Adamowski J. 2014. Spatial and temporal trends of mean and extreme rainfall and temperature for the 33 urban centres of the arid and semi-arid state of Rajasthan, India. Atmospheric Research 138: 73-90.

DOI: $10.1016 /$ j.atmosres.2013.10.024

Pingale SM, Khare D, Jat MK, Adamowski J. 2016. Trend analysis of climate variables in an arid and semi-arid region of the Ajmer district, Rajasthan, India. Journal of Water and Land Development 28: 3-18.

DOI: 10.1515/jwld-2016-0001

Prakash C, Rao DH. 1986. Frequency analysis of rain data for crop planning (Kota). Indian Journal of Soil Conservation 14(2): 23-26.

Rajeevan M, Bhate J. 2009. A high resolution daily gridded rainfall dataset (1971-2005) for mesoscale meteorological studies. Current Science 96: 558-562.

Reddy GVS, Bhaskar SR, Purohit RC, Chittora AK. 2008. Markov chain model probability of dry, wet weeks and statistical analysis of weekly rainfall for agricultural planning at Bangalore. Karnataka Journal of Agricultural Science 21: 12-16.

Reddy SJ. 1990. Methodology: Agro-climate analogue technique and applications as relevant to dry land agriculture. Agro climatology series Eth 86/21-WMO/ UNDP, NMSA, Addis Abeba, Ethiopia, 60 pp.

Roy I. 2017. Indian summer monsoon and El Niño-Southern Oscillation in CMIP5 models: A few areas of agreement and disagreement. Atmosphere 8(154): 1-13. DOI: $10.3390 /$ atmos 8080154

Rupa Kumar K, Pant GB, Parthasarathy B, Sontakke NA. 1992. Spatial and sub-seasonal patterns of long-term trends of the Indian summer monsoon rainfall. International Journal of Climatology 12: 257-268.

DOI: $10.1002 /$ joc.3370120303

Sahai AK, Grimm AM, Satyan V, Pant GB. 2003. Longlead prediction of Indian summer monsoon rainfall from global SST evolution. Climate Dynamics 20: 855-863. DOI: $10.1007 / \mathrm{s} 00382-003-0306-8$

Shannon CE. 1948. A mathematical theory o communication. Bell System Technical Journal 27: 379-423. DOI: 10.1002/j.1538-7305.1948.tb01338.x

Sharma HC, Chauhan HS, Ram S. 1979. Probability analysis of rainfall for crop planning. Journal of Agricultural Engineering 16: 87-94.

Sharma J, Thakur DR. 1995. Contingent crop planning for rainy days and winter seasons in rainfed mid-hill conditions of Himachal Pradesh. Indian Journal of Agronomy 40: 557-562.

Singh N, Ranade AA. 2009. Climatic and hydroclimatic features of wet and dry spells and their extremes across India. Research Report No. RR-122. Indian Institute of Tropical Meteorology, Pune.

DOI: 10.13140/RG.2.1.5180.6881

Srivastava AK, Rajeevan M, Kshirsagar SR, 2008. Development of a high-resolution daily gridded temperature data set (1969-2005) for the Indian region. Research Report No. 8/2008. National Climate Centre, India Meteorological Department, Pune.

Syroka J, Toumi R. 2004. On the withdrawl of the Indian summer monsoon. Quarterly Journal of the Royal Meteorological Society 130: 989-1008.

DOI: $10.1256 /$ qj.03.36

Tettey M. Oduro FT, Adedia D, Abaye DA. 2017. Markov chain analysis of the rainfall patterns of five geographic locations in the southeastern coast of Ghana. Earth Perspectives 4: 1-11.

DOI: $10.1186 / \mathrm{s} 40322-017-0042-6$

Wilks DS, Wilby RL. 1999. The weather generation game: a review of stochastic weather models. Progress in Physical Geography 23: 329-357.

DOI: /10.1177/030913339902300302

Yemenu F, Chemeda D. 2010. Climate resources analysis for use of planning in crop production and rainfall water management in the central highlands of Ethiopia, the case of Bishoftu district, Oromia region. Hydrology and Earth System Sciences-Discussions 7: 3733-3763. DOI: 10.5194/hessd-7-3733-2010 